$\begin{array}{llllllll}\text { A } & \mathrm{R} & \mathrm{T} & \mathrm{Y} & \mathrm{K} & \mathrm{U} & \mathrm{E} & \mathrm{Y}\end{array}$

ALICJA SZULC

RENATA WILGOSIEWICZ-SKUTECKA

\title{
O poznańskich rękopisach i starych drukach w zbiorach Biblioteki Uniwersyteckiej w Uppsali ${ }^{1}$
}

\begin{abstract}
Streszczenie. Artykuł jest prezentacją wyników wstępnej kwerendy w Bibliotece Uniwersyteckiej w Uppsali, przeprowadzonej 14-18 maja 2012 roku. Jej celem był ogólny przegląd najstarszej części księgozbioru pod kątem znajdujących się w nim rękopisów i starych druków zrabowanych w 1656 roku z bibliotek poznańskich jezuitów, bernardynów i dominikanów. W części wstępnej artykułu przedstawione zostały szwedzkie grabieże księgozbiorów w XVII wieku, starania rewindykacyjne Rzeczypospolitej oraz badania naukowe nad polskimi księgozbiorami w Szwecji prowadzone od XIX wieku. Podstawę źródłową kwerendy stanowiły przechowywane w archiwum Biblioteki Uniwersyteckiej w Uppsali niepublikowane notatki bibliograficzne Józefa Trypućki (1910-1983), językoznawcy i bibliografa szwedzkich poloników, wieloletniego profesora Uniwersytetu w Uppsali. Materiał ten - efekt kwerendy Trypućki w zasobach Carolina Rediviva - zawiera cenne informacje dotyczące starych druków i rękopisów proweniencji poznańskiej. Zbiory wielkopolskie znajdujące się w Uppsali nie doczekały się dotąd szczegółowych badań. Niniejszy artykuł jest próbą nakreślenia kierunku i metod dalszych badań.
\end{abstract}

SŁowA KLuczowe: poznańskie biblioteki klasztorne XVII wieku, księgozbiór kolegium jezuickiego w Poznaniu, bernardyni, dominikanie, Biblioteka Uniwersytecka w Uppsali, szwedzkie grabieże księgozbiorów w XVII wieku.

1 Niniejszy artykuł został opublikowany w przekładzie szwedzkim: Redogörelse för efterforskningar i Sverige. Om handskrifter och äldre tryck från Poznań $i$ Uppsala universitetsbiblioteks samlingar, przeł. M. Białecka, „Biblis” 2014, t. 66, s. 52-65. 


\begin{abstract}
Nadszedł teraz czas na monograficzne opracowanie poszczególnych księgozbiorów; przede wszystkim mam tu na myśli biblioteki warmińskie i poznańskie, których rekonstrukcja, na zasadzie zachowanych katalogów, nie będzie przedstawiać poważniejszych trudności wobec skupienia głównego ich trzonu w Uppsali².
\end{abstract}

Choć minęło prawie 100 lat od sformułowania przez Aleksandra Birkenmajera powyższego postulatu badawczego, został on zrealizowany jedynie w części i wciąż pozostaje aktualny. Zważywszy na zakres strat kulturalnych poniesionych przez Rzeczpospolita $w$ toku licznych wojen ze Szwedami w XVII-XVIII wieku oraz wielkość bezpowrotnie utraconych polskich księgozbiorów kościelnych i prywatnych, taki stan badań może zastanawiać i wręcz zdumiewać. Dlatego każda kolejna inicjatywa badawcza w tym zakresie, choćby zawężona chronologicznie i terytorialnie, wydaje się godna odnotowania.

Niniejszy artykuł w zasadniczej części ma formę sprawozdania z wyników wstępnej kwerendy w Bibliotece Uniwersyteckiej w Uppsali, przeprowadzonej w terminie 14-18 maja 2012 roku. Jej celem był rekonesans, ogólny przegląd najstarszej części księgozbioru pod kątem znajdujących się w niej rękopisów i starych druków proweniencji poznańskiej, przede wszystkim zrabowanych w 1656 roku z bibliotek poznańskich jezuitów, bernardynów i dominikanów. Przechowywane w Carolina Rediviva w Uppsali wielkopolskie zbiory nie doczekały się bowiem dotychczas szczegółowych badań ani całościowego opracowania. Mamy świadomość, iż podejmując się tego z wielu względów trudnego zadania zainicjowania nowego, poznańskiego czy - szerzej - wielkopolskiego kierunku „poszukiwań w Szwecji", włączamy się w nurt trwających od XIX wieku badań nad rodzimym dziedzictwem kulturowym, rozproszonym i bezpowrotnie utraconym w wojnach toczonych na przestrzeni wieków.

Impulsem i swego rodzaju punktem odniesienia do naszych poszukiwań stał się Katalog księgozbioru Kolegium Jezuitów w Braniewie zachowanego $w$ Bibliotece Uniwersyteckiej w Uppsali - owoc wielu lat badań prof. Józefa Trypućki. Uzupełniony i opracowany przez Michała Spandowskiego i Sławomira Szyllera został wydany w 2007 roku (projekt Uppsala Universitetsbibliotek i Biblioteki Narodowej w Warszawie) ${ }^{3}$. Edycja ta jest

2 A. Birkenmajer, Ksiażka O. Waldego o szwedzkich zdobyczach bibljotecznych, „Exlibris" 1924 , t. 5 , s. 78.

3 J. Trypućko, Katalog księgozbioru Kolegium Jezuitów w Braniewie zachowanego w Bibliotece Uniwersyteckiej w Uppsali, uzupełnił. M. Spandowski, oprac. M. Spandowski, S. Szyller, t. 1-3, Warszawa-Uppsala 2007. O badaniach Józefa Trypućki i okolicznościach wydania katalogu braniewskiego w dalszej części artykułu. 
najbardziej szczegółowym i w dużej mierze wzorcowym opracowaniem jednego z największych polskich księgozbiorów kościelnych zrabowanych przez Szwedów, dlatego do niej jeszcze powrócimy.

\section{Szwedzkie grabieże księgozbiorów w XVII wieku i starania rewindykacyjne Rzeczypospolitej do 1795 roku}

Pierwsze straty biblioteczne, jakie poniosła Rzeczpospolita w czasie licznych wojen ze Szwedami w XVII-XVIII wieku, datuje się na rok 1621, wyprawę Gustawa II Adolfa na Inflanty - ziemie lenne Korony. $\mathrm{Z}$ pobudek ideologicznych rekwirowano w pierwszej kolejności księgozbiory jezuitów - głównego filaru kontrreformacji, dlatego pierwsza łupem Szwedów padła wówczas biblioteka kolegium jezuitów w Rydze, licząca około 1000 woluminów. Podobnie jak kilka kolejnych zdobytych księgozbiorów stała się zrębem tworzonego od 1620 roku księgozbioru biblioteki Uniwersytetu Królewskiego w Uppsali (Kongliga Universitetet i Uppsala $)^{4}$. Zrabowane $\mathrm{w}$ Mitawie archiwum zakonu mieczowego (około 1100 woluminów) przewieziono natomiast do Archiwum Narodowego w Sztokholmie (Riksarkivet). Podczas podjętej w 1626 roku wyprawy na teren Prus zostały splądrowane i wywiezione cenne księgozbiory warmińskie: biblioteka pierwszego w Polsce kolegium jezuitów w Braniewie (około 2700 woluminów, w całości włączona do biblioteki w Uppsali), biblioteka i archiwum kapitulne we Fromborku, wraz ze średniowiecznym zasobem kapitulnym oraz księgozbiorem Mikołaja Kopernika, a także część biblioteki cystersów w Pelplinie (około 160 woluminów, przewiezione do biblioteki w Linköping) i Oliwie (późniejsze losy nieznane).

Kolejny etap kradzieży polskich księgozbiorów przypadł na okres II wojny północnej (1655-1660). Wojska Karola X Gustawa, plądrując ziemie Rzeczypospolitej, zagrabiły wiele prywatnych i kościelnych księgozbiorów. Na terenie Wielkopolski łupem najeźdźców padła na początku część archiwaliów katedry w Gnieźnie (wywieziona do Riksarkivet w Sztokholmie), a następnie bogate księgozbiory Poznania: biblioteka kolegium jezuitów (w całości), część bibliotek klasztornych bernardynów i dominikanów

\footnotetext{
4 O. Walde, Histoire des Bibliothèques Suédoises, Paris 1949, s. 125-126.

5 C. Pilichowski, Z dziejów szwedzkich zaborów bibliotek i archiwów polskich w XVII i XVIII wieku, Gdańsk 1960, s. 5; D. Matelski, Straty polskich dóbr kultury w wojnach z sasiadami w XVII i XVIII wieku, „Muzealnictwo” 2003, t. 44, s. 7-27.
} 
oraz w ograniczonym zakresie księgozbiór kapituły katedralnej ${ }^{6}$. Zbiory poznańskie przejęte przez wojennego radcę dworu Claesa Rålamba przewiezione zostały w 1656 roku najpierw do jego biblioteki w Länna, skąd w 1693 roku trafiły ostatecznie do Uppsali ${ }^{7}$. Na Mazowszu największe straty poniosły archiwa i biblioteki Warszawy. Pod komendą kanclerza Eryka Oxenstierny wywieziono Archiwum Metryki Koronnej, bibliotekę Zygmunta III, królewicza Karola Ferdynanda, księgozbiór jezuitów, kamedułów na Bielanach i kilka innych. Do utraconych w tym czasie księgozbiorów należały także biblioteki jezuickie w Bydgoszczy i Toruniu, zagrabione i przejęte przez dyplomatę szwedzkiego Scheringa Rosenhane ${ }^{8}$. W różnym stopniu rozproszone zostały również księgozbiory jezuitów w Malborku, Wilnie, Krakowie, Grudziądzu, Jarosławiu, Lublinie, Sandomierzu, Rawie, kartuzów w Gdańsku i wiele innych. Według obliczeń w latach 1600-1721 Szwedzi zrabowali na terenie Rzeczypospolitej łącznie 67 bibliotek kościelnych i prywatnych (w całości lub częściowo) oraz 16 archiwów9.

Na podstawie zapisu traktatu pokojowego w Oliwie z 3 maja 1660 roku (§ IX) jeszcze tego samego roku rozpoczęto starania rewindykacyjne zagrabionych archiwów i księgozbiorów. Nie przyniosły one jednak nigdy oczekiwanych rezultatów. Wysłany w 1660 roku przez stronę polską Godfryd von Schröer z Gdańska uzyskał jedynie zwrot akt z archiwum i biblioteki królewskiej oraz części Metryki Koronnej i Litewskiej. Efektem kolejnej, dwuletniej (1680-1682) misji płk. Jakuba Bernika była rewindykacja fragmentów znacznie rozproszonego w bibliotekach szwedzkich księgozbioru Zygmunta Augusta i Zygmunta III Wazy ${ }^{10}$. Odzyskane książki królewskie zostały włączone do księgozbioru Jana III Sobieskiego. Wielki pożar Biblioteki Królewskiej (i całego zamku) w Sztokholmie w 1697 roku, gdzie przechowywano znaczną część skradzionych archiwaliów i ksiąg, jak również kolejne szwedzkie grabieże w czasie III wojny północnej (m.in. w latach 1703-1704 archiwum i biblioteka w Lidzbar-

6 C. Pilichowski, Straty bibliotek $i$ archiwów polskich podczas szwedzkiego "potopu” 1655-1660, w: Polska w okresie drugiej wojny pótnocnej 1655-1660, red. K. Lepszy, t. 2: Rozprawy, Warszawa 1957, s. 462.

7 O. Walde, Histoire des Bibliothèques..., s. 127. O losach księgozbiorów z Poznania i bibliotece Claesa Rålamba szerzej w dalszej części artykułu.

8 O. Walde, Storhetstidens Litterara Krigsbyten: En Kulturhistorisk-Bibliografisk Studie, t. 2, Uppsala 1920, s. 148.

9 D. Matelski, Straty polskich dóbr kultury w wojnach ze Szwecją z XVII i XVIII w. oraz próby ich restytucji, „Archeion” 2003, t. 106, s. 125.

${ }^{10}$ W. Konopczyński, Polska a Szwecja od pokoju oliwskiego do upadku Rzeczypospolitej, Warszawa 1924, s. 23; A. Birkenmajer, Bernikg (Bernik) Jakub, w: Polski słownik biograficzny, t. 1, Kraków 1935, s. 465. 
ku) jeszcze bardziej uszczupliły stan polskich księgozbiorów. W XVIII wieku podjęto dwie kolejne misje rewindykacyjne, które nie przyniosły żadnych wymiernych efektów. Około 1730 roku nieoficjalną podróż do Uppsali odbył bp Józef Andrzej Załuski, znany bibliofil i mecenas kultury (współzałożyciel Biblioteki Załuskich), a w latach 1788-1790 z inicjatywy Stanisława Augusta Poniatowskiego przebywała w Szwecji delegacja posła Jerzego M. Potockiego, w której znalazł się znany badacz, jezuita Jan Albertrandi. Jedynym trwałym efektem poszukiwań Albertrandiego w Szwecji są jego rękopiśmienne notatki Iter Suecicum ${ }^{11}$.

\section{Badania naukowe nad polskimi księgozbiorami w Szwecji od XIX wieku}

W ciagu XIX wieku podejmowane były przez polskich badaczy „wycieczki” (jak określali je współcześni) do Szwecji mające głównie cele badawcze - rozpoznanie liczby wywiezionych poloników oraz ich obecnej lokalizacji. Jedynie przeprowadzona w 1810 roku z polecenia ks. Adama Czartoryskiego misja zaufanego sekretarza i bibliotekarza z Puław Felicjana Biernackiego miała ponadto cele rewindykacyjne. Książęcemu wysłannikowi udało się odzyskać kilka rękopisów przechowywanych w Bibliotece Królewskiej w Sztokholmie (m.in. Diariusz sejmu w Piotrkowie w 1562 roku) oraz wykupić trzynastotomową korespondencję warmińską zagrabioną przez Szwedów we Fromborku, a znajdującą się w tym czasie w Bibliotece Uniwersyteckiej w Uppsali ${ }^{12}$. Kolejne wyprawy za Bałtyk, już wyłącznie o charakterze poznawczym, podejmowali w tym okresie polscy badacze, przede wszystkim historycy: w 1844 roku hr. Eustachy Tyszkiewicz (Listy o Szwecyi, Wilno 1846), w 1892 roku Józef Korzeniowski (wyniki nieopublikowane), cztery lata później Aleksander Hirschberg (Z wycieczki naukowej do Szwecyi, Lwów 1896) oraz Ludwik Antoni Birkenmajer, który badając spuściznę naukową Mikołaja Kopernika, odbył dwie podróże do Szwecji - w 1897 i 1908 roku (Mikołaj Kopernik. Studya nad pracami Kopernika oraz materyały biograficzne, Kraków 1900, 1909). Były to jednak zwykle poszukiwania fragmentaryczne, a publikowane wyniki miały często charakter przyczynkarski.

${ }^{11}$ Z. Anusik, Misja polska w Sztokholmie w latach 1789-1795, Łódź 1993, s. 85-90; A. Schletz, Ks. Jan Albertrandi w latach 1731-1795, „Nasza Przeszłość” 1959, t. 10, s. 177-208.

12 Odzyskane archiwalia znalazły się w zbiorach Muzeum Książąt Czartoryskich. Szczegóły i efekty tej misji opisał C. Pilichowski, Z dziejów szwedzkich..., s. 22 i n. 
Dopiero ekspedycja badawcza Eugeniusza Barwińskiego, Ludwika Birkenmajera i Jana Łosia podjęta w 1911 roku z inicjatywy Akademii Umiejętności w Krakowie zainicjowała zakrojone na szerszą skalę kwerendy $\mathrm{w}$ szwedzkich bibliotekach i archiwach, rozpoczęła tym samym etap wnikliwych i szczegółowych badań nad utraconymi księgozbiorami. Należy przy tym zauważyć, iż ze względu na argument przedawnienia, jak również na zmieniającą się sytuację polityczną na arenie międzynarodowej (wizja odrodzenia państwa polskiego) działania podejmowane przez stronę polską na początku XX wieku (i w ciągu całego stulecia) mogły już mieć jedynie charakter ekspedycji naukowych zmierzających do oszacowania, choćby w przybliżeniu, wielkości strat poniesionych przez Rzeczpospolitą w XVII i na początku XVIII wieku w zakresie zbiorów archiwalno-bibliotecznych. Barwiński opisywał w 1914 roku cel odbytej kwerendy: „ekspedycya [...] mając z góry określony sześciotygodniowy czas trwania, miała $\mathrm{w}$ tym czasie przeszukać wszystkie zbiory szwedzkie, zbadać i opisać wszystkie w nich znajdujące się Polonica do Szwecyi wywiezione" ${ }^{\prime \prime}$. W gronie badaczy znalazł się także syn prof. Ludwika Birkenmajera - Aleksander, ówczesny student historii na Uniwersytecie Jagiellońskim, późniejszy dyrektor Biblioteki Jagiellońskiej, Biblioteki Uniwersytetu Poznańskiego i profesor Uniwersytetu Warszawskiego. Poszukiwania w 1911 roku były przełomowe również ze względu na międzynarodowy, polsko-szwedzki charakter. Grupę historyków z Galicji wsparł bowiem na miejscu Isak Collijn (1875-1945), starszy bibliotekarz w Uppsali, znawca szwedzkich księgozbiorów ${ }^{14}$. W ciągu wspomnianych sześciu tygodni udało się odnaleźć i zidentyfikować 205 rękopisów (w tym dziewięć poznańskich) oraz 160 nieznanych druków polskich z XVI-XVII wieku (w tym osiem poznańskich), bo tylko takie polonika szwedzkie - w nieznanych lub zapomnianych wydaniach - były przedmiotem zainteresowania krakowskiej ekspedycji ${ }^{15}$.

Pisząc o rozwoju badań naukowych nad polskimi księgozbiorami w Szwecji na początku XX wieku, należy także przywołać postać Ottona Waldego (1879-1963), bibliotekarza Biblioteki Uniwersyteckiej w Uppsali, który pracę doktorską i całe swoje życie naukowe poświęcił badaniom i identyfikacji księgozbiorów zagrabionych w trakcie wojen prowadzonych

${ }^{13}$ E. Barwiński, L. Birkenmajer, J. Łoś, Sprawozdanie z poszukiwań w Szwecyi dokonanych z ramienia Akademii Umiejętności, Kraków 1914, s. XX.

${ }^{14}$ I. Collijn, Katalog der Inkunabeln der Schwedischen öffentlichen Bibliotheken, t. 2: Katalog der Inkunabeln der Kgl. Universitäts-Bibliothek zu Uppsala, Uppsala 1907.

15 Powyższe dane liczbowe podaje E. Barwiński w przedmowie do Sprawozdania z poszukiwań w Szwecyi..., s. XXII i XXV. 
przez Szwecję w Europie w XVII-XVIII wieku' ${ }^{16}$. Po ukazaniu się w 1920 roku drugiego tomu monumentalnego dzieła Waldego Storhetstidens Litterara Krigsbyten: En Kulturhistorisk-Bibliografisk Studie Aleksander Birkenmajer szczegółowo zreferował jego treść i zrecenzował na łamach „Exlibrisu” w 1924 roku, akcentując wartość rozprawy dla polskich badaczy:

Anormalne stosunki, w jakich od wojny bytuje nauka polska, były powodem, że dopiero przed niedawnym czasem doszedł moich rąk drugi tom pięknej książki dra Ottona Waldego [...] o „literackich zdobyczach wojennych z czasów potęgi" Szwecji. [...] Z naszej strony musimy nazwać to dzieło, a zwłaszcza jego II-gi tom, jedną z najważniejszych książek do historii bibliotek w Polsce. Bez jej znajomości niepodobna dziś napisać prawdziwych dziejów naszych księgozbiorów w XVI i XVII wieku; na niej będą się musiały oprzeć wszelkie dalsze badania $\mathrm{w}$ tym zakresie. A do zrobienia pozostaje jeszcze sporo, nawet co do tych bibliotek, którymi się Walde zajmował ${ }^{17}$.

Miał rację Aleksander Birkenmajer, określając dzieło Ottona Waldego jako fundamentalne dla kolejnych pokoleń badaczy poloników w archiwach i bibliotekach Szwecji. Stanowiło ono bowiem punkt odniesienia w badaniach podejmowanych po 1945 roku i nadal pozostaje podstawowym opracowaniem dla współcześnie zajmujących się tą problematyką. Do zawartych w nim ustaleń odwoływał się także Józef Trypućko (1910-1983), językoznawca, slawista, tłumacz, bibliograf, który swoje życie zawodowe (od 1939 roku) związał z Uniwersytetem w Uppsali ${ }^{18}$ i odegrał szczególną rolę $\mathrm{w}$ powojennym etapie badań nad polskimi księgozbiorami przechowywanymi w uppsalskiej Carolina Rediviva. W 1958 roku wydał drukiem katalog Polonica Vetera Upsaliensia i planował zrekonstruowanie katalogu dawnej biblioteki jezuitów w Braniewie. Trypućko pracował nad projektem przez wiele lat, lecz z różnych powodów nie udało mu się tego wielkiego zadania sfinalizować. Pozostawił po sobie maszynopis katalogu w wersji prymarnej, który zgodnie z ostatnią wolą autora miał zostać uzupełniony, poprawiony i wydany.

Początkowo podjął się tego zadania Jakub Z. Lichański, pracownik Biblioteki Narodowej w Warszawie. Ostatecznie jednak na mocy umowy zawartej w 1989 roku między Biblioteką Uniwersytecką w Uppsali a Biblioteką

${ }^{16}$ O. Walde, Storhetstidens Litterara Krigsbyten: En Kulturhistorisk-Bibliografisk Studie, t. 1-2, Uppsala 1916, 1920 (dalej cytujemy tylko tom drugi).

${ }^{17}$ A. Birkenmajer, Ksiażka O. Waldego o szwedzkich zdobyczach bibljotecznych, „Exlibris" 1924 , t. 5 , s. 65 i 78.

${ }^{18}$ W latach 1966-1977 pełnił funkcję dyrektora Instytutu Języków Słowiańskich na Uniwersytecie w Uppsali. 
Narodową w Warszawie zainicjowano wspólny projekt wydania katalogu Józefa Trypućki - w formie wykazu książek proweniencji braniewskiej znajdujących się aktualnie w Carolina Rediviva ${ }^{19}$. Opracowanie katalogu powierzono pracownikom Biblioteki Narodowej - Michałowi Spandowskiemu (stare druki) i Sławomirowi Szyllerowi (rękopisy). Podjęte przez nich uzupełnienia, korekty i weryfikacje maszynopisu Trypućki oraz dalsze poszukiwania niezidentyfikowanych jeszcze druków ${ }^{20}$ przeciągnęły się na kolejne lata, lecz wydany w 2007 roku Katalog... jest opracowaniem imponującym, rzetelnym i - co najważniejsze - wyraźnie korygującym dotychczasową wiedzę o stanie zachowania księgozbioru jezuitów z Braniewa ${ }^{21}$. Ostateczna liczba zawartych w Katalogu... książek o proweniencji braniewskiej obejmuje: 58 rękopisów, 336 inkunabułów i 2255 druków z XVI-XVII wieku ${ }^{22}$. O tym, jak ogólna i mglista była wcześniej wiedza na temat zasobu braniewskiego (i pozostałych wywiezionych archiwów i bibliotek), w jakim stopniu nierozpoznana i bazująca na niezweryfikowanych przekazach, świadczą dane liczbowe podawane w powojennej literaturze przedmiotu i powielane przez badaczy jeszcze w XXI wieku ${ }^{23}-$ zob. tabela.

Tabela. Księgozbiór braniewski w Bibliotece Uniwersyteckiej w Uppsali

\begin{tabular}{|l|c|c|}
\hline & $\begin{array}{c}\text { Stan badań } \\
\text { do 2007 roku }\end{array}$ & $\begin{array}{c}\text { Według badań Józefa Trypućki oraz } \\
\text { Michała Spandowskiego i Sławomira Szyllera }\end{array}$ \\
\hline Rękopisy & 16 & $\begin{array}{c}58 \\
\text { (43 współoprawne z drukami) }\end{array}$ \\
\hline Inkunabuły & 187 & $336(348$ egz.) \\
\hline Druki XVI-XVII wieku & 1333 & $2255(2339$ egz.) \\
\hline
\end{tabular}

Źródło: Opracowanie własne.

${ }^{19}$ O szczegółach tego projektu, jego realizacji i ostatecznych wynikach: M. Spandowski, S. Szyller, Wprowadzenie, w: J. Trypućko, op.cit., t. 1, s. 31 i n.

${ }^{20} \mathrm{Na}$ podstawie szczegółowej kwerendy przeprowadzonej z autopsji w 2002 roku przez Michała Spandowskiego, z pomocą pracowników Biblioteki Uniwersyteckiej w Uppsali - Harriet Wallman i Mirki Białeckiej - udało się odnaleźć i dodać do katalogu osiem nowych inkunabułów i 654 druki z XVI-XVII wieku.

${ }^{21}$ Obecnie dobiega końca drugi etap projektu polsko-szwedzkiego - konwersja danych Katalogu... z formatu MAK do formatu MARC21 i wprowadzenie do bazy szwedzkiego katalogu centralnego LIBRIS.

22 M. Spandowski, S. Szyller, op.cit., s. 33.

${ }^{23}$ Por. D. Matelski, Straty polskich dóbr kultury..., s. 7. Jak pisał Czesław Pilichowski w 1960 roku: „Ilość zabranych dzieł w Braniewie wyniosła według dotychczasowych ustaleń - 1520, w tym 187 inkunabułów, z Fromborka - 225, w tym 94 inkunabuły, ilość rękopisów - 68 z Fromborka i 16 z Braniewa" (C. Pilichowski, Z dziejów szwedzkich..., s. 7). 


\section{Księgozbiory poznańskie w Bibliotece Uniwersyteckiej w Uppsali - historia i stan obecny}

Książnica braniewska była najważniejszym, lecz nie jedynym przedmiotem poszukiwań Józefa Trypućki podczas jego licznych kwerend w zasobach Biblioteki Uniwersyteckiej w Uppsali. W materiałach archiwalnych Trypućki znajdują się dwa pudła skoroszytów ${ }^{24} \mathrm{z}$ odręcznymi opisami poloników zagrabionych przez Szwedów z wielu miast i klasztorów Rzeczypospolitej. Obok najliczniej reprezentowanych księgozbiorów warmińskich i pomorskich oraz pojedynczych zabytków biblioteki Zygmunta Augusta i jezuitów ryskich, najwięcej po „braniewskich" - skoroszytów (14) to stare druki proweniencji poznańskiej. Duża liczba zidentyfikowanych i opisanych przez Trypućkę uppsalskich poznanianów dowodzi jego szczególnego zainteresowania księgozbiorami wywiezionymi ze stolicy Wielkopolski i uzasadnia podjęte przez profesora dalsze prace nad tą kolekcją poloników. Trypućko wspominał o tym w liście zawierającym jego naukową ostatnią wolę: "Zacząłem porządkować bibl[iotekę] Poznańską - zwróć uwagę na dopisek: Red. ostateczna. Kartki bez tego odnośnika należałoby skonfrontować z odnośnymi drukami" (List do Andrzeja, z lipca 1983 roku $)^{25}$.

W trakcie pięciodniowej kwerendy w Bibliotece Uniwersyteckiej w Uppsali (14-18 maja 2012 roku) udało nam się przeanalizować materiał zawarty w siedmiu z czternastu wspomnianych skoroszytów poznańskich Trypućki. Każdy z nich zawiera średnio około 100-110 fiszek z opisami poszczególnych druków. Ogólna liczba druków (egzemplarzy) o proweniencji poznańskiej wynosi 748, w tym:

- z księgozbioru kolegium jezuitów 477,

- z księgozbioru klasztoru bernardynów 39,

- z księgozbioru klasztoru dominikanów 12,

- z księgozbiorów kościelnych 24,

- z Poznania (tj. druki o niezidentyfikowanej bliżej proweniencji) 196.

Jak wspomniano, przedstawione dane to wyniki analizy zaledwie połowy zebranego przez Trypućkę materiału poznańskiego. Przyjmując, iż pozostałych siedem skoroszytów zawiera w przybliżeniu opisy 700-800 druków, łączna szacunkowa liczba druków o rozpoznanej proweniencji poznańskiej wynosi około 1450-1550 woluminów. Pojawia się jednak pytanie, jak duża to część księgozbiorów wywiezionych z Poznania w 1656 roku. Jaki procent zasobu przechowywanego do dziś w Uppsali udało się Trypućce zidentyfikować i opisać?

${ }^{24} \mathrm{UB}$, sygn. 538 E: 1, 538 F:2.

${ }^{25}$ List publikowany - Wprowadzenie, w: J. Trypućko, op.cit., t. 1, s. 15-16. 
Wydaje się, iż odpowiedzi należałoby szukać przede wszystkim $\mathrm{w}$ zachowanym ( $w$ archiwum Caroliny) inwentarzu prywatnego księgozbioru radcy wojennego dworu Karola X Gustawa - Claesa Rålamba. Znany ze swych humanistycznych i bibliofilskich zainteresowań przejął zrabowaną w Poznaniu bibliotekę jezuitów oraz część księgozbiorów klasztornych bernardynów i dominikanów i wywiózł je w 1656 roku do swojej biblioteki w Länna ${ }^{26}$. Dopiero w 1693 roku, w ramach zwrotu długów zaciągniętych u króla, musiał je przekazać - wraz z całą swoją kolekcją - do Biblioteki Uniwersyteckiej w Uppsali. Rålamb sporządził wówczas inwentarz swojego księgozbioru ${ }^{27}$, odnotowując w nim ponad 3700 dzieł, w tym także książki zdobyte w Poznaniu. Na podstawie danych zawartych w rękopisie Rålamba Otto Walde ustalił orientacyjna, przybliżoną liczbę 2000 tomów proweniencji poznańskiej, w tym ponad 170 inkunabułów ${ }^{28}$. Wydaje się ona jednak zbyt mała w porównaniu choćby z zasobem biblioteki kolegium jezuitów poznańskich, szacowanym w połowie XVII wieku na ponad 6000 woluminów ${ }^{29}$. Nie zmienia to faktu, iż kolekcja Rålamba stanowi przypadek wyjątkowy wśród księgozbiorów wywiezionych do Szwecji, których - jak podkreślał Collijn - „inne wielkie części rozprószyły się i zniszczały"30. Choć poznaniana dotarły do Uppsali w zasadniczym zrębie w całości, nie uniknęły jednak akcji wydawania dubletów podejmowanej przez kolejnych dyrektorów Caroliny w XVIII-XIX wieku. Świadczą o tym pojedyncze egzemplarze druków proweniencji poznańskiej odnalezione w kilku innych bibliotekach szwedzkich (przede wszystkim w Linköping). Wszystkie wskazane kwestie pokazuja, jak trudno w istocie określić wielkość kolekcji poznańskiej w jej stanie pierwotnym, tj. w momencie przejęcia jej przez Rålamba, oraz w stanie obecnym.

${ }^{26}$ O. Walde, op.cit., s. 96-97.

${ }^{27}$ Inwentarz przechowywany w Bibliotece Uniwersyteckiej w Uppsali, sygn. U 281.

${ }^{28}$ Liczba inkunabułów poznańskich wykazanych w katalogu Collijna jest mniejsza, ponieważ Walde zrekonstruował wiele kolligatów rozerwanych przez Rålamba przed przekazaniem księgozbioru do Uppsali; zob. A. Birkenmajer, Książka O. Waldego..., s. 72, p. 7. Charakterystykę 166 inkunabułów poznańskich notowanych przez Collijna przedstawił A. Warschauer, Wiegendrucke aus Posener Büchersammlungen in der Universitäts-Bibliothek zu Uppsala, „Historische Monatsblätter für die Provinz Posen" 1908, nr 4, s. 57-65.

${ }^{29} \mathrm{~J}$. Wiesiołowski, O najstarszej bibliotece poznańskich jezuitów w świetle zachowanych w Szwecji katalogów bibliotecznych, „Kronika Miasta Poznania” 1997, nr 4, s. 128. Autor podaje szacunkową liczbę 8000 książek wywiezionych z Poznania w 1656 roku.

${ }^{30}$ Cyt. za: A. Birkenmajer, Książka O. Waldego..., s. 74. 
Odwołując się raz jeszcze do przykładu księgozbioru braniewskiego do wyraźnej korekty danych szacunkowych z początku XX wieku uzyskanej na podstawie badań Trypućki oraz Spandowskiego i Szyllera można z przekonaniem stwierdzić, iż prawdziwą odpowiedź na pytanie o wielkość poznańskiej kolekcji mogą dać jedynie dalsze wnikliwe kwerendy w najstarszych zasobach Biblioteki Uniwersyteckiej w Uppsali polegające na rejestracji proweniencji starych druków z autopsji.

$\mathrm{Na}$ obecnym etapie badań możemy scharakteryzować interesujące nas zbiory - przede wszystkim najlepiej udokumentowaną bibliotekę kolegium jezuitów - jedynie na podstawie przekazów źródłowych dotyczących księgozbiorów z Poznania i ich właścicieli, katalogów Biblioteki Uniwersyteckiej w Uppsali oraz w świetle przeanalizowanej części materiałów Józefa Trypućki. Informacje o zidentyfikowanych rękopisach pochodzące $\mathrm{z}$ literatury przedmiotu i inwentarzy - w nieznacznym tylko stopniu dopełnią tę charakterystykę.

\section{Księgozbiór kolegium jezuitów}

Utworzone w Poznaniu w latach 1570-1571 kolegium Towarzystwa Jezusowego - podobnie jak inne szkolne placówki jezuitów na ziemiach polskich doby kontrreformacji - od początku rozwijało się dynamicznie, do tego stopnia, iż w początkach XVII wieku pretendowało do uzyskania rangi uniwersytetu ${ }^{31}$. Wraz z rozpoczęciem działalności szkolnej w 1573 roku zaczęto gromadzić i profilować księgozbiór, początkowo głównie dzięki darom licznych dobrodziejów - poznańskich i wielkopolskich dostojników kościelnych, duchownych i świeckich zwolenników idei propagowanych przez Towarzystwo Jezusowe. Znaczącą darowiznę stanowiła część dużego księgozbioru kolegiaty św. Marii Magdaleny, przekazana jezuitom w 1605 roku przez bp. Wawrzyńca Goślickiego $\mathrm{w}$ porozumieniu $\mathrm{z}$ władzami miejskimi ${ }^{32}$. Sukcesywny napływ darów książkowych (często w postaci zapisów testamentowych), a także zwiększająca się stopniowo liczba nabytków na drodze zakupów sprawiły, że księgozbiór jezuitów już w połowie XVII wieku był większy od połączonego zasobu wszystkich ówczesnych instytucji kościelnych Poznania (z bibliotekami klasztornymi i katedralną włącznie). Szacuje się, że był

${ }^{31}$ O dziejach poznańskiego kolegium jezuitów i jego staraniach o statut uniwersytecki zob. Wokół jezuickiej fundacji uniwersytetu z 1611 roku, red. D. Żołądź-Strzelczyk, R. Witkowski, Poznań 2011.

32 O. Walde, op.cit., s. 95, 133. 


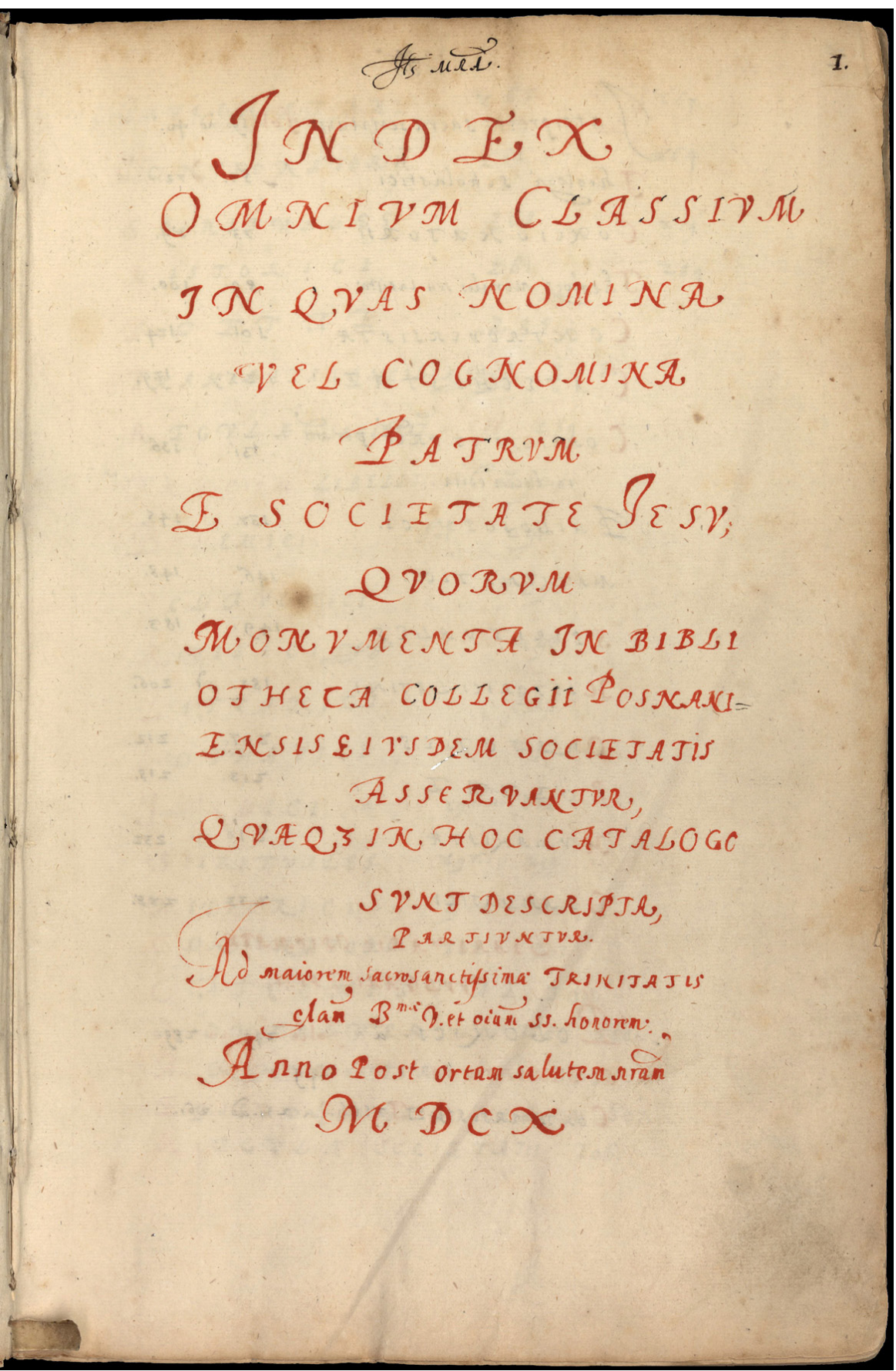

Il. 1. Index Bibliothecae Collegii Posnaniensis e Societate Jesu, 1610 Źródło: Biblioteka Uniwersytecka w Uppsali, sygn. C 533. 
drugim bądź trzecim co do wielkości księgozbiorem naukowym na ziemiach Rzeczypospolitej (po bibliotece Akademii Krakowskiej, a być może na równi z biblioteką kolegium jezuickiego w Wilnie ${ }^{33}$.

O objętości, charakterze i profilu biblioteki kolegium poznańskiego świadczy zawartość rękopiśmiennych katalogów z 1609 (katalog ogólny) i 1610 roku (katalog dzieł autorów jezuickich - il. 1), które należą do najstarszych zachowanych inwentarzy bibliotek jezuickich w Polsce $^{34}$. W 1656 roku zostały wywiezione wraz z całym księgozbiorem i do dziś znajdują się w Bibliotece Uniwersyteckiej w Uppsali ${ }^{35}$. Nie analizując wnikliwie układu rzeczowego obu inwentarzy ${ }^{36}$, należy jedynie zaznaczyć, iż zastosowany w katalogach podział rzeczowy oraz proporcje ilościowe między poszczególnymi działami potwierdzają charakterystyczny dla jezuitów profil kształcenia, w którym pierwszorzędną rolę odgrywają wiedza religijna, humanistyka oraz filozofia, w dalszej kolejności zaś nauki matematyczno-przyrodnicze i prawo.

Jak wynika z późniejszych wpisów (po 1609 i 1610 roku), oba katalogi uzupełniano do 1630 roku i na tej podstawie można ustalić szacunkową liczbę zinwentaryzowanych książek kolegium jezuitów w pierwszej połowie XVII wieku. Catalogus universalis librorum Collegii Posnaniensis (U 276) zawierał około 1630 roku co najmniej 4728 egzemplarzy, a Index Bibliothecae Collegii Posnaniensis e Societate Jesu (U 275) około 1603 egzem-

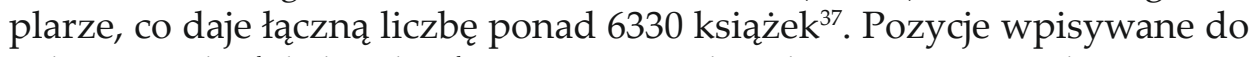
jednego z dwóch katalogów otrzymywały także stosowną adnotację na karcie tytułowej: Inscriptus Catalogo librorum Collegii Posnaniensis Societatis Jesu (z datą rejestracji lub bez), występującą też w formie skróconej. Ta nota proweniencyjna jest podstawową i najbardziej czytelną wskazówką w identyfikacji z autopsji książek należących do największej ze zrabowanych bibliotek poznańskich (il. 2).

33 Podajemy za J. Wiesiołowskim, op.cit., s. 132.

${ }^{34}$ Szczegółową charakterystykę tych katalogów przeprowadził R. Witkowski, Biblioteka jezuicka w świetle katalogów z początku XVII wieku, w: Wokót jezuickiej fundacji uniwersytetu..., s. 175-204 (tu także pełna literatura przedmiotu).

${ }^{35}$ Index Bibliothecae Collegii Posnaniensis e Societate Jesu, Bibl. arkiv. U 275; Catalogus universalis librorum Collegii Posnaniensis, Bibl. arkiv. U 276.

${ }^{36}$ Zagadnienie omawiają szczegółowo: J. Wiesiołowski, op.cit., s. 127 i n.; R. Witkowski, op.cit., s. 181 i n.

37 Podajemy za J. Wiesiołowskim, op.cit., s. 128-130. 


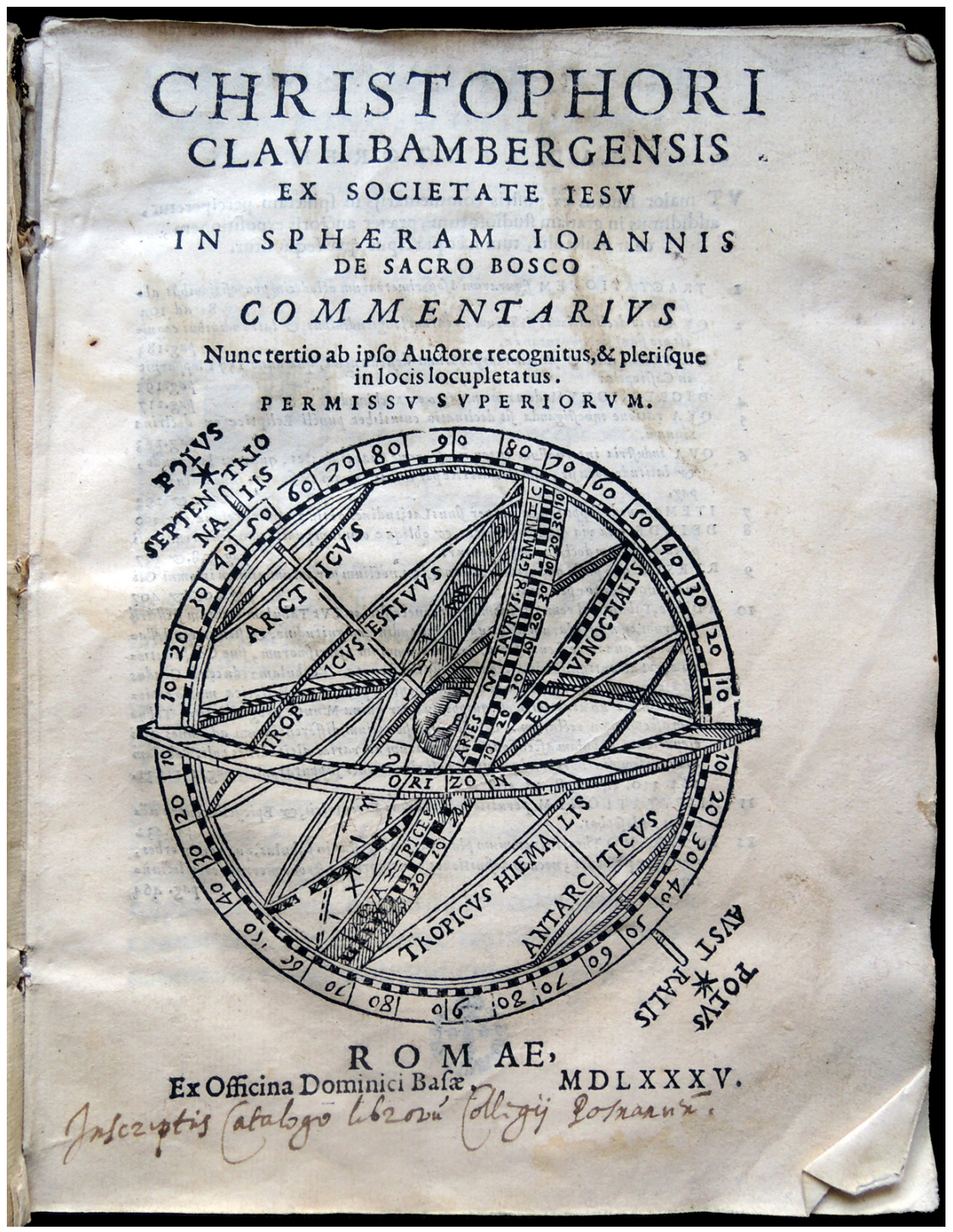

Il. 2. Christophori Clavii... in sphaeram Ioanis de Sacro Bosco commentarius, Romae 1585, z notą proweniencyjną biblioteki kolegium jezuitów: Inscriptus Catalogo librorum Collegii Posnaniensis Societatis Jesu

Źródło: Biblioteka Uniwersytecka w Uppsali, fot. Renata Wilgosiewicz-Skutecka. 


\section{Księgozbiory klasztorne bernardynów i dominikanów}

Stosunkowo najmniej wiemy o bibliotekach dwóch z najstarszych klasztorów poznańskich, których zbiory również częściowo padły łupem Szwedów. Zarówno dominikanie, sprowadzeni na poznańską Śródkę przed 1239 rokiem, jak i bernardyni (franciszkanie obserwanci), działający w Poznaniu od 1455 roku, od początku gromadzili książki (zwłaszcza dzięki darom) i tworzyli biblioteki, przeznaczone jednak wyłącznie na użytek wewnątrzklasztorny, indywidualnego studium zakonników. Nigdy więc nie osiagnnęły one wielkości zasobów porównywalnej z księgozbiorem jezuickim, kształtowanym głównie na potrzeby kolegium. Jak inne stare biblioteki powstałe w XIII-XV wieku wyróżniały się z pewnością bogatym zbiorem kodeksów średniowiecznych.

Niewiele wiadomo o najstarszej bibliotece dominikanów, ponieważ spłonęła w pożarze w 1464 roku, a odbudowa księgozbioru trwała wiele lat. W 1525 roku dzięki wsparciu biskupa sufragana Wojciecha z Sochaczewa udało się wznieść nowy budynek przeznaczony pro libraria ${ }^{38}$.

Najstarsze wzmianki o zasobie księgozbioru bernardynów pochodzą dopiero z pierwszej połowy XVII wieku. Według Augustyna Cieplińskiego, lektora poznańskiego studium i późniejszego kronikarza polskiej prowincji bernardynów, biblioteka poznańska liczyła przed 1652 rokiem 666 druków in folio, 600 in octavo, 306 in quarto oraz 28 rękopisów (w tym 10 dzieł kaznodziejskich w 16 woluminach) ${ }^{39}$.

Brak zachowanych najstarszych inwentarzy bibliotek poznańskich klasztorów sprawia, że o ich zasobie i układzie rzeczowym do XVII wieku można wnioskować jedynie na podstawie zachowanych egzemplarzy oraz analogii do innych rozpoznanych księgozbiorów dominikańskich i bernardyńskich. W każdej z bibliotek klasztorów żebraczych uwidaczniał się bowiem charakterystyczny dla zakonów mendykanckich profil duszpasterski. Największą część księgozbiorów stanowiły pozycje z zakresu biblistyki, patrystyki, literatury kaznodziejskiej i ascetycznej oraz historii Kościoła ${ }^{40}$.

Zadziwia nieco fakt, że ani w kronikach bernardynów poznańskich, ani w źródłach dominikańskich nie znajdujemy wzmianki o rabunku

${ }^{38}$ J.A. Spież, Dominikanie w Poznaniu, „Kronika Miasta Poznania” 2004, nr 3, s. $13-14$.

${ }^{39}$ Podajemy za J.A. Mazurkiem, Bernardyni w Poznaniu 1455-1655, „Studia Franciszkańskie" 1991, t. 4, s. 270.

40 S.B. Tomczak, Biblioteka bernardynów w Poznaniu od początku fundacji do XVII w., „Studia Franciszkańskie” 1991, t. 4, s. 329-332. 
klasztornego księgozbioru w 1655 roku. Czyżby straty książkowe nie były dla obu konwentów na tyle dotkliwe, aby poświęcić im kilka słów na kartach kronik? Bardziej prawdopodobne wydaje się jednak, iż rzutowała na to ogólna trudna sytuacja egzystencjalna poznańskich i wielkopolskich klasztorów podczas szwedzkiej okupacji - zniszczonych, ograbionych, obciążonych kontrybucjami ${ }^{41}$. Szczególnie dotkliwe straty poniósł wówczas klasztor bernardynów, który po wypędzeniu braci przez wojsko szwedzkie na trzy lata musiał zawiesić swoją działalnośćc ${ }^{42}$.

Jak już wspomniano, biblioteki poznańskich dominikanów i bernardynów nie zostały zrabowane w całości i trudno stwierdzić, w jakim stopniu uległy rozproszeniu i zniszczeniu w trakcie ataku wojsk szwedzkich na budynki klasztorne w 1655 roku. Fragmentaryczność tej części wywiezionego z Poznania księgozbioru potwierdza stosunkowo mały odsetek „pozajezuickich" egzemplarzy przechowywanych w Uppsali. Przypomnijmy 39 druków (w tym 4 inkunabuły) o potwierdzonej proweniencji bernardyńskiej i 12 (1 inkunabuł) z biblioteki dominikanów na ogólną liczbę przebadanych 748 opisów książek poznańskich. Typowe dla biblioteki bernardynów noty proweniencyjne, na podstawie których można identyfikować poszczególne egzemplarze, przyjmują różne formy, występujące także w wariantach skróconych: Pro libraria loci Posnaniensis, Pro bibliotheca PP. Bernardinorum, Loci Posnaniensis PP. Bernardinorum, Pro bibliotheca Posnaniensi apud FF. Bernardinos, Pro cella praedicatorum posnaniensis PP. Bernardinorum. Najczęściej spotykane na kartach tytułowych, okładkach lub wyklejkach wpisy potwierdzające proweniencję dominikańską to: Pro bibliotheca conventus Posnaniensis S. Dominici, ad bibliothecam conventus posnaniensis ordinis Praedicatorum.

\section{Poznańskie rękopisy - próba charakterystyki}

Kodeksy rękopiśmienne stanowią najmniejszą i jak dotąd najsłabiej rozpoznaną część księgozbiorów poznańskich przechowywanych w Uppsali. Na podstawie informacji zawartych w katalogach rzeczowych rękopisów Biblioteki Uniwersyteckiej w Uppsali oraz w literaturze przedmiotu można przyjąć liczbę 18 manuskryptów o potwierdzonej proweniencji poznańskiej, z czego 16 to kodeksy jezuickie, pozostałe dwa pochodzą z biblioteki bernardynów. W grupie tej znajdują się cztery

${ }^{41}$ J.A. Spież, op.cit., s. 16.

42 Por. Kroniki Bernardynów poznańskich, oprac. S.B. Tomczak, J. Wiesiołowski, Poznań 2002, s. 186-187. 
rękopisy średniowieczne - dwa bernardyńskie (C 533, C 630) i dwa jezuickie (C 49, C 800) ${ }^{43}$.

Najcenniejszym i najstarszym rękopisem jest XIII-wieczny kodeks zawierający Dekretaty Grzegorza IX z glosami Bernarda de Botone (C 533) ${ }^{44}$. Pergaminowa księga formatu folio została zapisana w dwóch kolumnach wczesną odmianą włoskiej rotundy (littera bononiensis) przez skryptora, który odnotował swoje imię na k. 288 v: Expliciunt decretales de manu Henrici Lescot. U dołu pierwszej karty znajduje się XVII-wieczny wpis proweniencyjny: Pro Conventu Posnaniensi Ff Bernardinorum ${ }^{45}$. Dodatkowym elementem identyfikującym ten kodeks jako polski jest napis Kokoscha (słabo czytelny) umieszczony na przedniej części oprawy. Charakteryzując ten cenny zabytek, nie sposób nie wspomnieć o jego wartości artystycznej i estetycznej. Bogato zdobione inicjały, liczne i misternie wykonane miniatury, różnorodne drolerie o bogatej treści symbolicznej, wykorzystane do dekoracji marginalnej każdej z kart rękopisu, stanowią ciekawy i cenny przykład wysokiego kunsztu XIII-wiecznego iluminatorstwa włoskiego (il. 3).

Drugi z kodeksów bernardyńskich, o sygn. C 630, składa się z dwóch części datowanych na XIV i XV wiek (w późniejszym okresie zszytych razem). Zawiera dzieła trzech średniowiecznych teologów zakonnych: św. Bonawentury oraz Piotra z Rosenheim i Hugona Ripelina ze Strasburga $^{46}$. W zakończeniu pierwszego traktatu (k. 49 r) skryptor zanotował: Explicit Breuiloquium domini Bonaventure In tarnow per manus fratris pancracii mazouite scriptum sub anno Incarnacionis dni MilCCCCLXXXI. Na odwrocie przedniej okładki zapisano w XVI wieku Pro libraria loci Posnanien[sis]

${ }^{43}$ M. Andersson-Schmitt, H. Hallberg, M. Hedlund, Mittelalterliche Handschriften der Universitätsbibliothek Uppsala. Katalog über Die C-Sammlung, t. 1-8, Stockholm 1988-1995 (dalej cyt. Mittelalterliche Handschriften...). Katalog także w wersji elektronicznej bazy Manuscripta Mediaevalia: http://www.manuscripta-mediaevalia.de/hs/ kataloge/HSK0506a.htm.

${ }^{44}$ Decretales Gregorii IX cum glossa Bernardi Parmensis de Botone. Perg., folio, $42 \mathrm{x}$ 26 cm, k. 299, Bolonia, koniec XIII w., C 533; E. Barwiński, L. Birkenmajer, J. Łoś, Sprawozdanie, nr 110, s. 76; Mittelalterliche Handschriften..., t. 5: C 401-550, Stockholm 1992, s. 336-337.

${ }^{45}$ Należy zaznaczyć, iż w opisie kodeksu C 533 w Mittelalterliche Handschriften... autorzy katalogu, powołując się na monografię O. Waldego (op.cit., t. 2, s. 99), podają błędną informację, iż rękopis ten został zrabowany przez Szwedów w trakcie wojny trzydziestoletniej. O. Walde wymienia Decretales Gregorii IX jako zdobycz szwedzką z 1655 roku.

46 Bonawentura. Petrus de Rosenheim. Hugo Ripelin de Argentina. Perg., octavo, 18,5 x 13,5 cm, k. 157, Tarnów, 1481. XIV w., C 630; Mittelalterliche Handschriften..., t. 6 : C 551-935, Stockholm 1993, s. 162-163. 


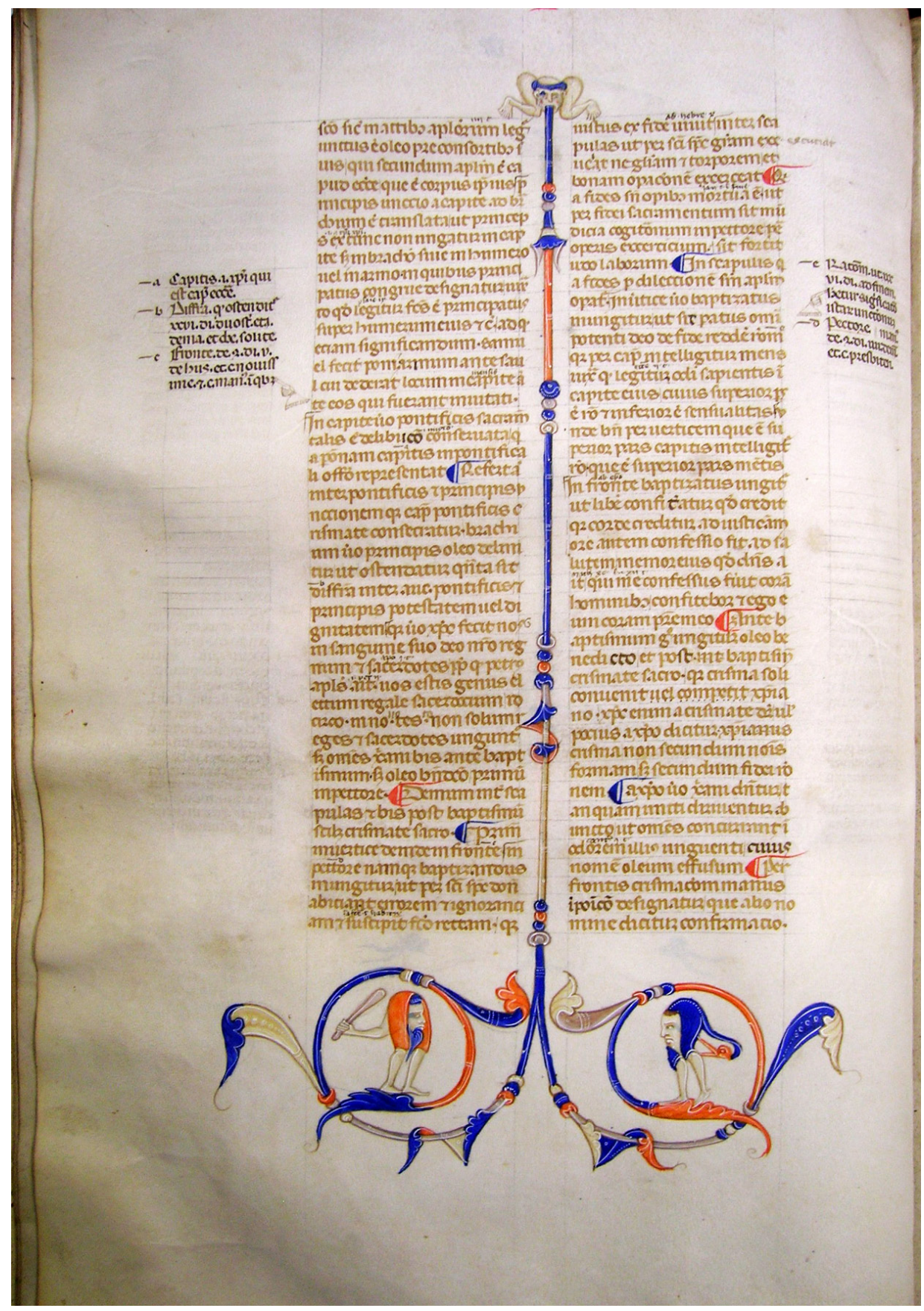

\section{Il. 3. Decretales Gregorii IX cum glossa Bernardi Parmensis de Botone, Bolonia,} koniec XIII wieku

Źródło: Biblioteka Uniwersytecka w Uppsali, sygn. C 533, fot. Renata Wilgosiewicz-Skutecka. 
(il. 4). Na tej podstawie w katalogu szwedzkim odnotowano, że kodeks ten pochodzi prawdopodobnie $z$ biblioteki kolegium jezuitów ${ }^{47}$. W opisie sporządzonym przez Birkenmajera brak jakiegokolwiek przypuszczenia czy uściślenia $\mathrm{w}$ tej kwestii ${ }^{48}$. Ustalona przez nas proweniencja bernardyńska kodeksu opiera się na dwóch przesłankach. Pierwszą jest nota proweniencyjna Pro libraria loci Posnaniensis - typowa dla druków należących do bernardynów. Drugi argument wiąże się z postacią skryptora pierwszej części kodeksu - brata Pankracego („Mazowity”?), który spisał Breviloquium w 1481 roku w Tarnowie. $Z$ dużym prawdopodobieństwem można przyjąć, iż wykonał tę pracę w skryptorium klasztoru bernardynów, który działał w tym mieście od 1459 roku. Droga książki z konwentu tarnowskiego do poznańskiego wydaje się już krótka, biorąc pod uwagę bliskie więzi wspólnotowe, mobilność braci i częste rotacje między klasztorami $\mathrm{w}$ ramach całej prowincji.

Najstarsze rękopisy z biblioteki kolegium jezuitów to Sankt Georgener Predigten - sporządzony $\mathrm{w}$ mitteldeutsch XV-wieczny odpis popularnego w Niemczech zbioru 39 kazań z klasztoru Sankt Georgen w Schwarzwaldzie (C 800 $)^{49}$ - oraz Collectio veterum inscriptionum latinarum, quae Romae et in vicino repertae fuerunt z początku XVI wieku (C 49) ${ }^{50}$. Szczególnie interesujący jest drugi manuskrypt, ponieważ spisał go Piotr Wedelicjusz z Obornik (zm. 1542), wybitny lekarz rodem z Wielkopolski, doktor medycyny uniwersytetu w Bolonii ${ }^{51}$ (przed 1516

${ }^{47}$ Ibidem, s. 163.

${ }^{48}$ E. Barwiński, L. Birkenmajer, J. Łoś, Sprawozdanie, s. 77, nr 112.

49 St. Georgener Predigten, mitteldeutsch. Perg., quarto, 20 x 14,5 cm, k. 175, Niemcy, 1. poł. XV w., C 800. Na k. 1 u dołu XVII-wieczny wpis: Inscriptus Catalogo librorum Collegii Posnaniensis Societatis Jesu 1609; E. Barwiński, L. Birkenmajer, J. Łoś, Sprawozdanie, s. 76, nr 111, tu tytuł opisowy: Meditationes religiosae super sententiis biblicis lingua germanica scriptae; O. Walde, op.cit., s. 100-101; Mittelalterliche Handschriften..., t. 6: C 551-935, s. 315-316.

50 Collectio veterum inscriptionum latinarum, quae Romae et in vicino repertae fuerunt. Papier, quarto, 21,5 x 14,5 cm, k. 214, Włochy Pół., pocz. XVI w., C 49; E. Barwiński, L. Birkenmajer, J. Łoś, Sprawozdanie, s. 130-131, nr 215; Mittelalterliche Handschriften..., t. 1: C I-IV, 1-50, Stockholm 1988, s. 333-334; o rękopisie także C. Lindsten, De codice Upsaliensi C 49, Gothoburgi 1916.

${ }^{51}$ Nie ma pewności, czy złożył promocję doktorską na tym uniwersytecie; z pewnością jednak na jednej z włoskich uczelni, niewykluczone, że w Padwie, gdzie kształciło się wielu polskich lekarzy; E. Stocki, Księgi medyczne lekarzy poznańskich w bibliotekach szwedzkich, „Kronika Miasta Poznania” 2001, nr 1, s. 82; R. Marciniak, Cztery podręczniki medyczne Piotra Wedelicjusza z Obornik w Bibliotece Poznańskiego Towarzystwa Przyjaciół Nauk (uwagi kodykologiczne), w: Scriptura custos memoriae. Prace historyczne, red. D. Zydorek, Poznań 2001, s. 425-426. 


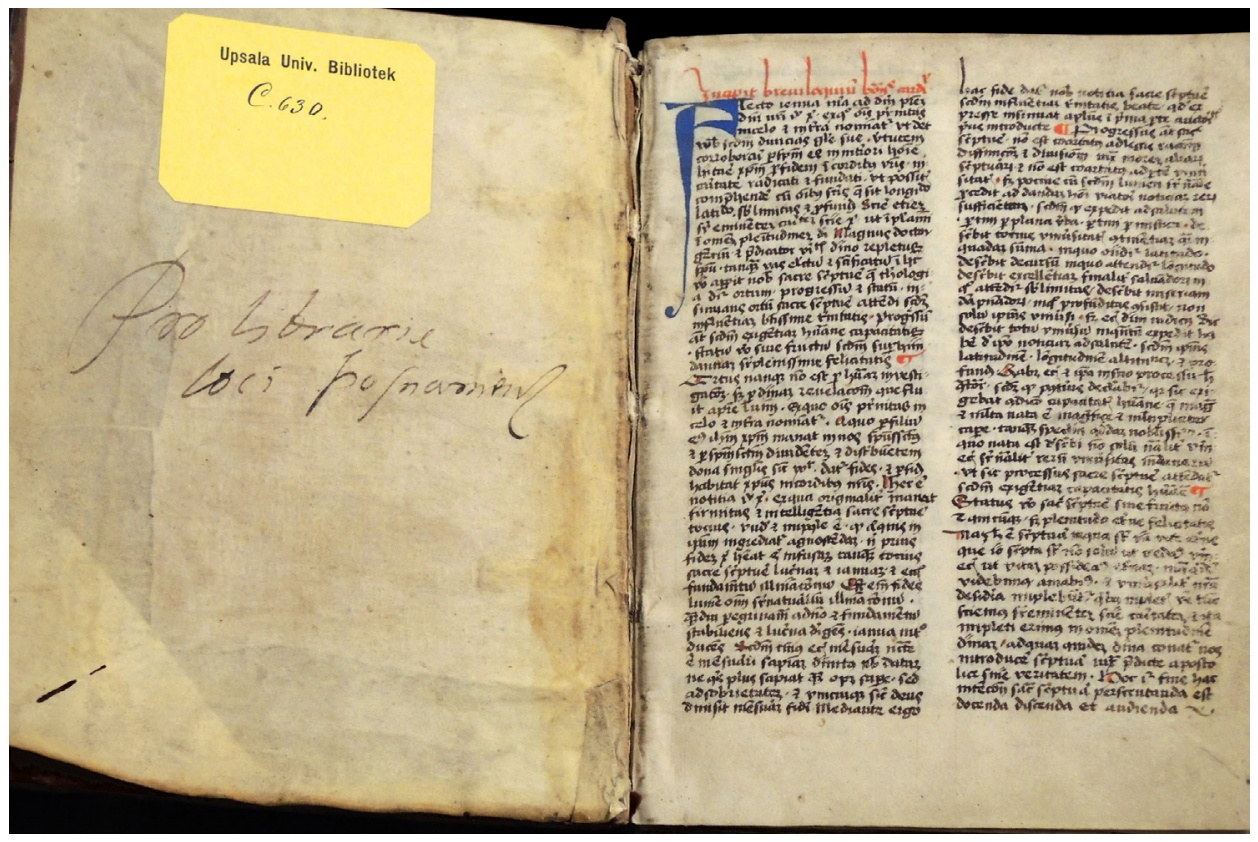

Il. 4. Breuiloquium domini Bonaventure..., Tarnów 1481, z notą proweniencyjną biblioteki bernardynów: Pro libraria loci Posnanien[sis]

Źródło: Biblioteka Uniwersytecka w Uppsali, sygn. C 630, fot. Renata Wilgosiewicz-Skutecka.

rokiem), rektor Uniwersytetu Jagiellońskiego, nadworny medyk Zygmunta I i królowej Bony. Rękopis ten jest bez wątpienia autografem, ponieważ forma podpisu na k. 6: Petri Jo. Vuibertini Obornicensis Poloni jest analogiczna do charakteru (duktu) pisma całego tekstu ${ }^{52}$. Nie można wykluczyć, iż 14 rysunków zdobiących manuskrypt (rzymskie mauzolea, tablice nagrobkowe, amfory), wykonanych współcześnie piórkiem i sepią to również dzieło uzdolnionego lekarza epoki renesansu. Nie wiadomo, w jaki sposób rękopis „rzymski” Wedelickiego oraz dwa należące do niego inkunabuły ${ }^{53}$ trafiły do poznańskiego kolegium jezuitów. Być może za pośrednictwem jego brata Jakuba, doktora teologii, proboszcza kościoła św. Marii Magdaleny, który mógł otrzymać je w spadku.

Do rękopisów jezuickich datowanych na XVI-XVII wiek zalicza się w pierwszej kolejności dwa rękopiśmienne katalogi biblioteki kolegium

${ }^{52}$ Inny, późniejszy charakter ma jedynie nota proweniencyjna na k. 7: Inscriptus Catalogo librorum Collegii Posnaniensis Societatis Jesu 1609.

${ }^{53}$ M. Moses, Aphorismi medici una cum aphorismis Johannis Damasceni et Rhasis, Bononiae 1489; I. Collijn, op.cit., nr 1069; M. Sylvaticus, Opus pandectarum medicinae, Strassburg ok. 1474; I. Collijn, op.cit., nr 1379. 
z 1609 (U 276) i 1610 roku (U 275), które trafiły do Uppsali wraz z całym księgozbiorem ${ }^{54}$. Najliczniejszą grupę tworzą dzieła teologiczne (10), wśród których występują także traktaty autorów jezuickich ${ }^{55}$. Pojedyncze egzemplarze reprezentują inne działy rzeczowe biblioteki kolegium. Są to: Arithmeticae Practicae breue Compendium. Calissij Anno Dni 1612 (A.25) oraz Tragediae scriptae - zbiór dramatów jezuickich spisanych około 1600 roku na użytek działalności teatralnej kolegium (R 380) ${ }^{56}$.

Oprócz przedstawionych rękopisów samodzielnych w zbiorach Biblioteki Uniwersyteckiej w Uppsali znajdują się też manuskrypty współoprawne z drukami. Wyłania się zatem kolejny postulat badawczy przebadania $\mathrm{z}$ autopsji adligatów rękopiśmiennych $\mathrm{w}$ inkunabułach i drukach proweniencji poznańskiej.

\section{Druki poznańskie i ich właściciele}

Analiza proweniencji księgozbiorów poznańskich pozwala tropić ślady historii pozostawione w przechowywanych w Uppsali drukach i rękopisach. Są to świadectwa życia naukowego i intelektualnego w Poznaniu XVI wieku, kontaktów lokalnego środowiska duchownych, profesorów, lekarzy, przedstawicieli władz miejskich.

W opisach druków poznańskich sporządzonych przez Trypućkę pojawiają się noty proweniencyjne wielu donatorów poznańskich bibliotek (przede wszystkim kolegium jezuitów), wśród nich kard. Stanisława Hozjusza (1504-1579), humanisty, sekretarza królewskiego, dyplomaty, czołowego przywódcy polskiej kontrreformacji57; arcybiskupów gnieźnieńskich: Stanisława Karnkowskiego i Andrzeja Krzyckiego; biskupów poznańskich: Adama Konarskiego, Jakuba Brzeźnickiego, Wawrzyńca Goślickiego, Stanisława Szedzińskiego, Kaspra Stanisława Happa; profesorów: Benedykta Herbesta, Stanisława Grzepskiego, Gabriela z Szadka, a także kilku poznańskich lekarzy: Jana Kosza, Jakuba Grodzickiego, Adama Paulinusa, Jana Chrościejewskiego, wybitnych jezuitów i wielu

${ }^{54}$ Zostały one omówione w ramach ogólnej charakterystyki biblioteki kolegium jezuickiego w Poznaniu.

${ }^{55}$ UB, T.164, T.316, T.323, T.324, T.352, T.356, T.362, Т.374, T.382, T.384.

${ }^{56}$ Rękopis ten jest dobrze znany w polskiej literaturze przedmiotu, zob.: J. Lewański, Kodeks poznański I (Uppsalski), w: Studia nad dramatem polskiego Odrodzenia, Wrocław 1956, s. 61-64; L. Winniczuk, Dramma comicum Odostratocles. Codex Uppsal. R 380, w: Orbis mediaevalis, Weimar 1970, s. 253-265.

57 W. Urban, Hozjusz Stanisław, w: Polski słownik biograficzny, t. 10, Kraków 1962-1964, s. 42-46. 
innych. Wpisy te pozwalają potwierdzić lub wręcz ustalić i datować pełnione przez nich funkcje i godności oraz ich kontakty naukowe. Czasem są to jedynie drobne zapiski proweniencyjne, np. Mathiae Smiglecii Posnanien. Rectori dignissimo ${ }^{58}$ - Marcina Śmigleckiego (1563-1618), filozofa i teologa, który w czasie studiów w Rzymie wstąpił do zakonu jezuitów, a po powrocie do kraju przez wiele lat był rektorem kolegiów w Pułtusku, Poznaniu i Kaliszu. W Uppsali przechowywane są również jego własne dzieła, np. wydane w Krakowie w 1614 roku Refutatio vanae dissolutionis nodi gordii de vocatione ministrorum... z zachowanym wpisem: Pro Coll. Posnan. Author dedit ${ }^{59}$.

Zapiski mniej lakoniczne, pełniejsze pozwalają na odczytanie złożonych relacji i kontaktów ówczesnego środowiska naukowego. Profesor uniwersytetu krakowskiego i kanonik poznański Gabriel z Szadka Szadkowski (XVI wiek) w dziele Plutarcha ${ }^{60}$ należącym wcześniej do Stanisława Grzepskiego (Stanislaus Grepsius wytłoczone na tylnej części oprawy) pozostawił ślad pamięci o swoim nauczycielu: Piae memoriae D[ominus] Stanislaus Grepsius dedit mihi facultatem suis libris utendi quam diu velle $[m]$. Hic ergo liber post meam mortem erit dandus ad Bibliotheca[m] Cracouien[sem] illi enim legaverat suos libros insigniores Gabr[iel] Sh[adcouius]scripsit ${ }^{61}$. Książka ta została później przekazana bibliotece jezuitów poznańskich, o czym świadczy wpis: Inscriptus Cat. Coll. Posnan. Soc. Jesu.

Podobne zapiski odnajdujemy na druku Gaspara Contariniego De magistratibus et republica venetorum wydanym w Bazylei w 1544 roku ${ }^{62}$, który już dwa lata później został podarowany Łukaszowi Górce, późniejszemu wojewodzie poznańskiemu, przez jego nauczyciela Eustachego Trepkę, wybitnego przedstawiciela luteranizmu: Lucas Comes de Gorka me Eustachio Trepka dono dedit Anno 1546. Druk ten znajdował się potem w posiadaniu lekarza Jakuba Grodzickiego i wraz z jego księgozbiorem został przekazany bibliotece jezuitów.

${ }^{58}$ L. Suslyga, Velificatio seu Theoremata..., Graecii 1605, UB, sygn. 69.175 (:2).

${ }^{59}$ M. Śmiglecki, Refutatio vanae dissolutionis..., Cracoviae 1614; zob. J. Trypućko, Polonica Vetera Upsaliensia, Uppsala 1958, s. 164.

${ }^{60}$ Plutarchus, Moralis opuscula..., Basileae 1542, UB, sygn. F 22; por. O. Walde, op.cit., s. 131.

61 „Pobożnej pamięci pan Stanisław Grzepski dał mi możliwość korzystania z jego ksiąg, jak długo zechcę. Ta zatem książka po mojej śmierci powinna zostać oddana do Biblioteki Krakowskiej przez tego, komu by swoje książki powierzył [...] Gabriel Szadkowski napisał" (tłum. R. Wójcik).

${ }^{62}$ G. Contarini, De magistratibus et republica venetorum, Basileae 1544, UB, sygn. Gg 184. 
Zapiski dokonane ręką osób wybitnych, zasłużonych mogą budzić szczególne zainteresowanie. Do takich należy z pewnością Andrzej Krzycki (1482-1537, łacińska forma nazwiska Cricius), arcybiskup gnieźnieński i prymas Polski, sekretarz królowej Bony, dyplomata, a także mecenas sztuki, pisarz i poeta ${ }^{63}$. W Uppsali znajduje się kilka ksiąg z jego biblioteki, wśród nich m.in. indeks do dzieł św. Augustyna wydany w Bazylei w 1529 roku $^{64}$, przekazany do biblioteki bernardynów w Poznaniu przez Łukasza Krzyckiego, bratanka Andrzeja, z zapiskiem na karcie tytułowej: Iste liberet sequentes concessus est pro cella predicatoris, in loco Posnaniensi ad Bernardinos per predicatorem Lucam Cricium eiusdem ordinis fratrem professum. Post mortem pie memoriae Reverendissimi Domini Andree Cricÿ Archiepiscopi Gnesnensis patroi sui oretur pro eo ut quiescat in pace ${ }^{65}$.

W Kronice Jezuitów poznańskich zawarte zostały wiadomości o dobroczyńcach kolegium i przekazanych przez nich księgozbiorach:

W pierwszych dniach sierpnia [1572 - A.S., R.W.S.] umarł przewielebny sufragan poznański Stanisław Szedziński [...]. Niemniej będąc na łożu śmierci, pozostawił po sobie trwały pomnik wyjątkowej życzliwości względem kolegium, ofiarował [nam] bowiem osobiście swoją bibliotekę obejmującą bogaty księgozbiór, która wydana nam po dwóch latach przez egzekutorów jego testamentu, znacząco wzbogaciła nasze nader skromne i ubogie zbiory ${ }^{66}$.

Wśród przebadanych opisów Józefa Trypućki znajduje się dziewięć druków ze zbiorów Szedzińskiego z wpisem Stanisl. Schedzinskij sufrag. Posnan $^{67}$.

Jeszcze więcej - 22 egzemplarze - pochodzi z księgozbioru bp. Stanisława Karnkowskiego (1520-1603) ${ }^{68}$. Są to głównie XVI-wieczne druki z zakresu filozofii i teologii, wydawane w Paryżu, Lyonie, Strasburgu,

${ }^{63}$ J. Korytkowski, Arcybiskupi gnieźnieńscy, prymasowie i metropolici polscy od roku 1000 aż do roku 1821, t. 3, Poznań 1889, s. 1-44.

${ }^{64}$ Index omnium quae insigniter dicta sunt a diuo Augustino..., Basileae 1529.

65 „Ta książka i następne przyznana została celi kaznodziei w Poznaniu u bernardynów, przez kaznodzieję Łukasza Krzyckiego tegoż zakonu brata profesa. Po śmierci pobożnej pamięci Najczcigodniejszego Pana Andrzeja Krzyckiego, Arcybiskupa Gnieźnieńskiego, jego stryja. Módl się za niego, by odpoczywał w pokoju" (tłum. R. Wójcik).

${ }^{66}$ Kronika Jezuitów poznańskich (młodsza), t. 1, oprac. L. Grzebień, J. Wiesiołowski, Poznań 2004, s. 15-16.

${ }^{67}$ UB, sygn. 36.158; 36.193; 56.6; 58.33; 58.98; 59.144; 68.433; 70.12; 71.26.

68 J. Korytkowski, op.cit., s. 419-540; H. Kowalska, Karnkowski Stanisław, w: Polski słownik biograficzny, t. 12, Kraków 1966-1967, s. 77-82. 
Kolonii, Bazylei i Wenecji, ale jest wśród nich również inkunabuł - dzieło włoskiego filozofa Aegidiusa Romanusa Expositio [...] supra libros elenchorum Aristotelis ${ }^{69}$ wydane w Wenecji w 1496 roku, świadczące o wysokiej wartości księgozbioru. Część tej kolekcji nosiła na oprawie inicjały biskupa: S K A G (Stanislaus Karnkowski Archiepiscopus Gnesnensis), inne oznaczane były pieczęcią: Stanis. Karnkowski. Archiep. Gneznen. O przekazaniu jego księgozbioru do biblioteki kolegium jezuitów świadczą wpisy na kartach tytułowych: Inscriptus catalogo collegij Posnaniensis Soc. Jesu. Donosi o tym także kronika klasztoru: „Jaśnie wielmożny i przewielebny Stanisław Karnkowski arcybiskup gnieźnieński, legat urodzony, prymas Królestwa Polskiego i pierwszy książę [...]. W 1583 roku podarował kolegium dość pokaźną bibliotekę"70.

Spośród ciekawych bibliotek XVI wieku - do których dziejów można by dopisać kolejną kartę, badając proweniencje ksiąg w Bibliotece Uniwersyteckiej w Uppsali - wymienić należy jeszcze zbiory Jakuba Brzeźnickiego (1540-1604), biskupa sufragana poznańskiego. Henryk Barycz pisał, że wyrazem jego wszechstronnych zainteresowań intelektualnych były „częste podróże do Włoch [...], nawiązywanie stosunków z wybitnymi uczonymi [...], wreszcie zapał do zbierania książek, których $\mathrm{B}$ [rzeźnicki] gromadzić nie przestawał od wczesnej młodości, był jednym z największych polskich zbieraczy książek w XVI wieku"71. Biskup Brzeźnicki przekazał kapitule poznańskiej swoją bibliotekę, z wyjątkiem części książek legowanych poznańskiemu kolegium. W zbiorach uppsalskich znaleźć można nie tylko ślady ksiąg darowanych jezuitom, ale również część księgozbioru biskupa, która przeszła w posiadanie jego bratanka - Andrzeja Brzeźnickiego, prepozyta kościoła św. Marii Magdaleny, zmarłego w 1625 roku. Bibliotekę tę spadkobiercy przekazali jezuitom w maju 1626 roku, a kronikarz tak odnotował ten fakt: „,wielebny Andrzej Brzeziński, proboszcz kościoła św. Marii Magdaleny w Poznaniu, legował drugi tysiąc florenów w bibliotece, którą nam pozostawił"72.

Analiza zapisków proweniencyjnych pozwala też śledzić zarówno wymianę idei i poglądów przez badanie rozprzestrzeniania się publikacji wydawanych poza granicami kraju, jak również bliskość kontaktów zwolenników

${ }^{69}$ Aegidius Romanus, Expositio [...] supra libros elenchorum Aristotelis, Venetiis 1496, UB, sygn. 31.213.

I. Collijn podaje siedem inkunabułów z proweniencją Stanisława Karnkowskiego, a H. Sallander notuje jeszcze jeden tegoż, Katalog der Inkunabeln der Kgl. UniversitätsBibliothek zu Uppsala, Uppsala 1953, s. 56.

${ }^{70}$ Kronika Jezuitów poznańskich..., s. 1.

${ }^{71}$ H. Barycz, Brzeźnicki Jakub, w: Polski słownik biograficzny, t. 3, Kraków 1937, s. 43.

${ }^{72}$ Kronika Jezuitów poznańskich..., s. 315, 511 (biogram Andrzeja Brzeźnickiego). 
polskiej kontrreformacji. Znakomitym przykładem może tu być dzieło Hozjusza Confessio catholicae fidei christiana ${ }^{73}$ wydane w Wiedniu w 1560 roku. Już we wrześniu tego roku Benedykt Herbest (około 1531-1598) - filolog klasyczny i pedagog, profesor Akademii Krakowskiej i rektor Akademii Lubrańskiego w Poznaniu, który w 1571 roku wstąpił do zakonu jezuitów i do ich biblioteki przekazał swój księgozbiór ${ }^{74}$ - podarował egzemplarz książki Hozjusza abp. Janowi Przerębskiemu, opatrując ją stosowną zapiską: Benedicto Herbesto Neapolitano à Reverendiss. D.D. Joanne Przerembski Archiepiscopo Gnesn. donat. Anno 1560 in Septembro.

Kilka przykładów zapisów proweniencyjnych pokazuje dobitnie, jak interesujące rezultaty można uzyskać, prowadząc systematyczne badania nad historycznym księgozbiorem. Wykonana przez nas kwerenda jest zatem jedynie punktem wyjścia, wstępem do dalszych poszukiwań, próbą nakreślenia kierunku i metod prowadzenia szczegółowych badań, które mamy nadzieję - zostaną w końcu podjęte, a ich wynikiem będzie opracowanie katalogu księgozbiorów poznańskich przechowywanych obecnie w zbiorach Biblioteki Uniwersyteckiej w Uppsali.

Zdobycie tak wielu cennych informacji bibliograficznych i źródłowych, przede wszystkim dotarcie do niewykorzystanych dotychczas materiałów archiwalnych Józefa Trypućki, a także ogólne zapoznanie z zasobem uppsalskich rękopisów i starych druków byłoby niemożliwe bez życzliwej pomocy i wsparcia pracowników Uppsala Universitetsbibliotek - w szczególności Pani Laili Österlund, dr Marii Berggren i Pani Mirki Białeckiej - którym składamy nasze serdeczne podziękowanie.

\author{
ALICJA SZULC \\ RENATA WILGOSIEWICZ-SKUTECKA
}

\title{
Some remarks on the manuscripts and old prints of Poznan provenance in the collection of the University Library in Uppsala
}

Aвstract. The present article aims at presenting a concise overview of the results of an initial search query and investigation carried out at the University Library in Uppsala between May 14-18, 2012. Its main goal was to get acquainted with the oldest part the

${ }^{73}$ S. Hosius, Confessio catholicae fidei christiana, Viennae 1560, UB, sygn. 72.29.

${ }^{74}$ K. Mazurkiewicz, Benedykt Herbest, Poznań 1925; J. Nowacki, Akademia Lubrańskiego, „Kronika Miasta Poznania” 1999, nr 2, s. 162-163. 
library's book collection in view of manuscripts and old books that came into possession of the library as spoils of war after they had been looted in Poznań-based libraries of the Jesuits, the Bernardines and the Dominicans in 1656. The introductory part of the article provides an outline of the history of the lootings by the Swedish armies of book collections in the seventeenth century, attempts at the restitution of the materials by the authorities of the Republic of Poland and the research on the Polish book collections currently held in Sweden that has been going on since the nineteenth century. The source base for the query was the unpublished bibliographical notes written by the Polish linguist, bibliographer of the material concerning Poland or Polish affairs kept in Sweden, and a long-term professor of the Uppsala University, Józef Trypućko (1910-1983) currently held in the archive material of the University Library in Poznań. The above material, the result of Trypućko's investigations on the resources of Carolina Rediviva, contains valuable information concerning old prints and manuscripts of Poznań provenience. Regrettably, the collections from Greater Poland that are currently held in Uppsala have not been yet properly researched and no all-inclusive study has been published. The present article attempts to provide tentative directions in future studies on the subject along with appropriate relevant methodology.

Key words: Poznań-based monastery, priory and convent libraries in the 17 th c., the book collection of the Jesuits Collegium in Poznan, the Bernardines, the Dominicans, University Library in Uppsala, Swedish plunder of book collections in the 17th c. Poland. 